\title{
Time-out duration and the control of an avoidance response rate
}

\author{
HARRY M. B. HURWITZ \\ University of Guelph, Guelph, Ontario, Canada \\ and \\ ALBERT E. ROBERTS \\ Catawba College, Salisbury, North Carolina 28144
}

\begin{abstract}
Rats were trained to avoid shock under a free operant avoidance procedure. After training, each session was divided into avoidance and time-out periods; that is, in separate blocks of sessions, the proportion of time assigned to time-out was varied between $1 / 4,1 / 2$, and $3 / 4$ of a session. As the duration of signaled time-out increased, the response rate during time-out decreased, with the greatest reductions obtained when $1 / 2$ or $3 / 4$ of the session involved time-out. When time-out was unsignaled, the response rate in time-out was diminished substantially only under the longest duration. Moreover, the rate of shock was elevated under the longest duration of unsignaled time-out.
\end{abstract}

A rat readily learns to discriminate a signaled period during which a free operant avoidance schedule (Sidman, 1953 ) is in effect from a period of time-out (Appel, 1960a). Typically, the relatively high rate of response originally established by the avoidance schedule declined in each time-out period over successive experimental sessions. However, Appel (1960a) also reported that the response rate of rats during the avoidance period itself declined and that this decline was associated with an increase in the number of shocks received. In a later study, Appel (1960b) reported that a discrimination between avoidance and time-out periods could be established with monkeys even when each was unsignaled. One difference in procedures between the two studies involved the length of time-out periods; in the rat study the avoidance period was twice the time-out period, namely, $20 \mathrm{~min}$ under avoidance and $10 \mathrm{~min}$ of time-out. In the monkey study, 5 min under avoidance alternated with either $10 \mathrm{~min}$ (ratio $1: 2$ ) or $5 \mathrm{~min}$ (ratio $1: 1$ ) time-out periods. While the development of differential responding under signaled extinctions was not surprising, the factors controlling the diminished response rate under unsignaled extinction is unclear. Apart from possible species differences, the acquisition of a discrimination between unsignaled avoidance and time-out could be sensitive to factors such as the responseshock interval, the intensity of shock, as well as the relative duration of avoidance to time-out. The present experiment focused on only one of these unexplored variables, namely, the proportion of a $2-\mathrm{h}$ session given over to time-out periods. Proportions of avoidance to time-out periods of $3: 1,1: 1$, and $1: 3$ were presented in separate blocks of sessions.

\section{METHOD}

\section{Subjects}

Eight female rats, purchased from Blue Spruce Farms, New York, served as subjects. Subjects weighed about $150 \mathrm{~g}$ at the beginning of the experiment and were housed three per cage with food and water always available.

\section{Apparatus}

Three operant chambers (Campden Instruments Company) measuring $25 \times 25 \times 21 \mathrm{~cm}$ were used. A $2.5 \times 5 \mathrm{~cm}$ lever was mounted in the center of one wall of the chamber $5 \mathrm{~cm}$ above the grid floor; a deadweight of $10 \mathrm{~g}(.1 \mathrm{~N})$ was needed on the lever to activate a microswitch. Grids of $.25-\mathrm{cm}$ stainless steel bars were spaced $1.3 \mathrm{~cm}$ apart parallel to the width of the lever. Shock was delivered to the grids, lever, and sides of the chamber via a relay scrambler. A light located in the middle of the ceiling of the chamber served as a houselight. Each chamber was placed in a larger sound-insulated box with a blower fan providing ventilation and a masking noise $(76 \mathrm{~dB})$.

\section{Procedure}

Avoidance training. Under the avoidance schedule used, subjects received a $.3-\mathrm{sec} .8-\mathrm{mA}$ shock every $5 \mathrm{sec}$ unless a leverpress occurred. Each lever response postponed shock for $20 \mathrm{sec}$. Houselights were off during all training sessions. A total of 25 2-h avoidance training sessions were given.

Time-out conditions. Phase $1: 3$. At the completion of training, subjects were arranged into two groups so that the shock rate for the groups was comparable. The avoidance schedule was suspended (time-out) on 24 occasions during each session. Each time-out period was $75 \mathrm{sec}$ and was given on the average of once every $4 \mathrm{~min}$; that is, on average $1 / 4$ of each session involved time-out. Each time-out period was signaled to four subjects (Group SIG) by turning on the houselight but was not signaled to four subjects (Group NSIG). Twenty-five sessions were given in this phase.

Phase $1: 1$. The time-out arrangement was continued except that each time-out period was increased to $150 \mathrm{sec}$. Thus, half of each session involved time-out. Fifteen sessions were given in this phase. 
Table 1

Mean Response and Shock Rates for Each Subject in Each Phase

\begin{tabular}{|c|c|c|c|c|c|c|c|c|c|c|}
\hline & \multirow[b]{3}{*}{$\mathrm{AV}$} & \multicolumn{8}{|c|}{ Proportion of Time-In to Time-Out Periods } & \multirow[b]{3}{*}{$\mathrm{AV}(\mathrm{R})$} \\
\hline & & \multicolumn{2}{|c|}{$3: 1$} & \multicolumn{2}{|c|}{$1: 1$} & \multicolumn{2}{|c|}{$1: 3$} & \multicolumn{2}{|c|}{$3: 1(\mathrm{R})$} & \\
\hline & & TI & TO & TI & TO & TI & TO & TI & To & \\
\hline NSIG 1 & $\begin{array}{c}6.4 \\
.84\end{array}$ & $\begin{array}{c}8.4 \\
.37\end{array}$ & 7.7 & $\begin{array}{l}6.8 \\
.46\end{array}$ & 5.9 & $\begin{array}{l}7.2 \\
1.30\end{array}$ & 3.7 & $\begin{array}{l}7.9 \\
.58\end{array}$ & 7.7 & $\begin{array}{l}8.0 \\
.35\end{array}$ \\
\hline NSIG 2 & $\begin{array}{l}5.7 \\
.99\end{array}$ & $\begin{array}{l}4.6 \\
1.26\end{array}$ & 2.7 & $\begin{array}{l}4.8 \\
1.52\end{array}$ & 1.6 & $\begin{array}{l}4.9 \\
1.78\end{array}$ & 1.2 & $\begin{array}{l}4.8 \\
1.09\end{array}$ & 3.2 & $\begin{array}{c}4.9 \\
.76\end{array}$ \\
\hline NSIG 3 & $\begin{array}{c}9.9 \\
.51\end{array}$ & $\begin{array}{c}8.9 \\
.31\end{array}$ & 8.0 & $\begin{array}{l}9.8 \\
.34\end{array}$ & 8.7 & $\begin{array}{l}8.6 \\
.38\end{array}$ & 7.2 & $\begin{array}{l}9.7 \\
.33\end{array}$ & 8.6 & $\begin{array}{c}10.1 \\
.27\end{array}$ \\
\hline NSIG 4 & $\begin{array}{c}5.6 \\
.99\end{array}$ & $\begin{array}{l}6.4 \\
1.20\end{array}$ & 3.9 & $\begin{array}{l}6.9 \\
1.63\end{array}$ & 2.6 & $\begin{array}{l}6.3 \\
2.03\end{array}$ & 1.5 & $\begin{array}{l}7.3 \\
1.04\end{array}$ & 5.9 & $\begin{array}{c}6.9 \\
.81\end{array}$ \\
\hline SIG 1 & $\begin{array}{l}9.1 \\
.27\end{array}$ & $\begin{array}{c}12.5 \\
.35\end{array}$ & 4.2 & $\begin{array}{c}32.3 \\
.10\end{array}$ & 9.9 & $\begin{array}{c}24.3 \\
.18\end{array}$ & 7.6 & $\begin{array}{c}27.9 \\
.11\end{array}$ & 13.9 & $\begin{array}{r}26.4 \\
.09\end{array}$ \\
\hline SIG 2 & $\begin{array}{c}6.4 \\
.75\end{array}$ & $\begin{array}{c}7.5 \\
.49\end{array}$ & 2.7 & $\begin{array}{c}9.7 \\
.84\end{array}$ & 1.0 & $\begin{array}{c}9.6 \\
.85\end{array}$ & .6 & $\begin{array}{l}8.1 \\
.46\end{array}$ & .5 & $\begin{array}{c}8.8 \\
.41\end{array}$ \\
\hline SIG 3 & $\begin{array}{l}5.0 \\
.95\end{array}$ & $\begin{array}{c}5.1 \\
.99\end{array}$ & 2.2 & $\begin{array}{l}5.7 \\
.80\end{array}$ & 1.7 & $\begin{array}{l}5.7 \\
.95\end{array}$ & .5 & $\begin{array}{c}4.6 \\
.96\end{array}$ & .9 & $\begin{array}{c}5.6 \\
.70\end{array}$ \\
\hline SIG 4 & $\begin{array}{r}18.0 \\
.88\end{array}$ & $\begin{array}{c}14.8 \\
1.09\end{array}$ & 3.3 & $\begin{array}{c}19.0 \\
1.85\end{array}$ & 1.2 & $\begin{array}{c}17.2 \\
1.98\end{array}$ & 1.2 & $\begin{array}{c}17.3 \\
1.06\end{array}$ & 1.6 & $\begin{array}{r}15.9 \\
.81\end{array}$ \\
\hline
\end{tabular}

Note-These are the mean responses per minute for subjects trained under unsignaled (NSIG) and signaled (SIG) time-out conditions. The means are based on the final five sessions of avoidance training $(A V)$ and retraining $[A V(R)]$ and each phase of the experiment. The mean shocks per minute for each phase are given in italics.

Phase 3:1. For 15 additional sessions, the length of each time-out period was $225 \mathrm{sec}$, so that $3 / 4$ of each session was spent in time-out.

Phase 1:3. The time-out length initially given $(75 \mathrm{sec})$ was reinstated for 15 sessions in this replication phase.

Avoidance retraining. The time-out condition was removed and 10 avoidance training sessions were given in the final phase of the experiment.

\section{RESULTS}

Mean response and shock rates for each subject, based on the final five sessions under each phase, are given in Table 1. Given the considerable betweensubjects differences in response rate, an index of discrimination was calculated from the response rate values (time-out/time-in) to provide a common point of reference; these values appear in Figure 1.

Table 1 shows the substantial lessening in time-out response rate for the subjects in the signal condition. The response rate during time-out was lowest when $1 / 2$ or $3 / 4$ of the session was given over to time-out (Phases $1: 1$ and $1: 3$, respectively). The level of timeout responding when most of the session involved avoidance depended upon whether that condition was given initially or following more extensive time-out experience (Phases 3:1 and 3:1 R): Time-out response rate was slightly lower in the latter phase for three subjects. The other subject (SIG 1) elevated markedly during Phase $1: 1$ and this elevated response rate evidently "carried over" into the time-out periods. The response rates of these subjects during the time-in

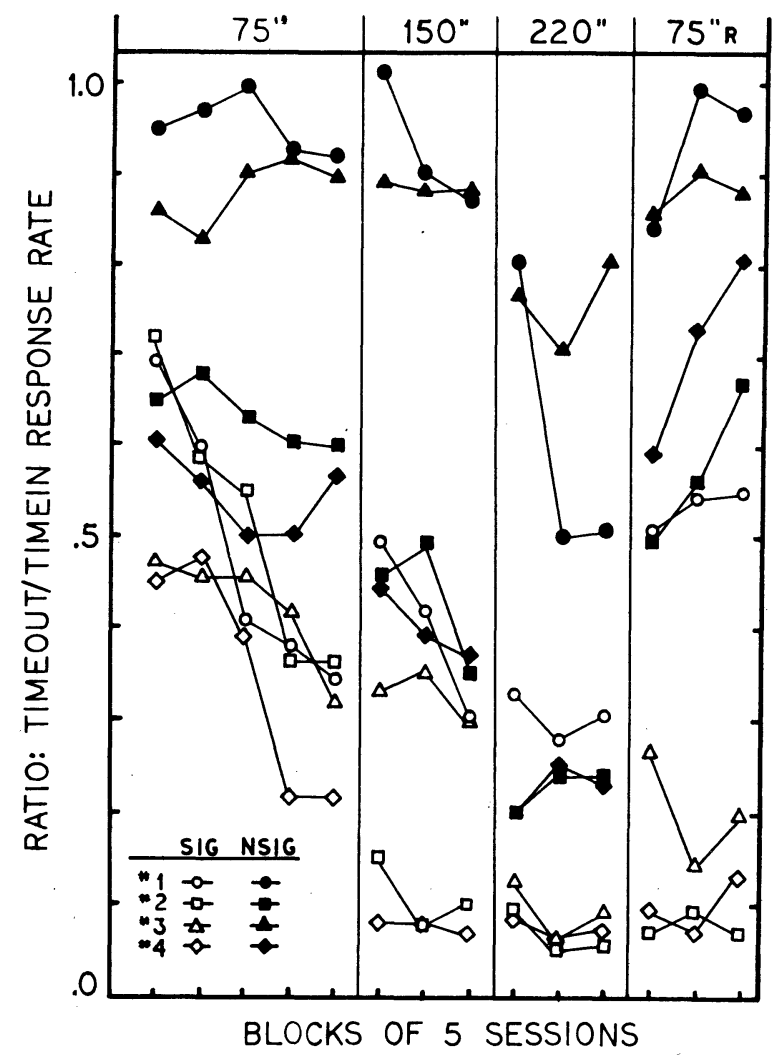

Figure 1. The index of discrimination for each subject based on mean time-out/time-in values. Each mean was based on five consecutive sessions in each phase. 
periods (including SIG 1) were not systematically influenced by either the presence of time-out or differing time-out durations.

Turning to the subjects under the unsignaled time-out conditions, the rate of response for these subjects during avoidance (TI) periods was not systematically altered by changes in the duration of time-out. The response rate during time-out was directly and monotonically related to time-out duration, that is, being lowest under the longest time-out periods (Phase $1: 3$ ). Moreover, Table 1 shows an interesting correspondence between shock rate and the discrimination between the two schedule components. The two subjects that showed the largest difference between avoidance and time-out response rates (NSIG 2 and 4) showed substantial increases in shock rate. The other two subjects (NSIG 1 and 3 ) actually had a reduced shock rate and a minimal response rate differentiation. The exception can be seen for NSIG 1 in Phase $1: 3$, during which the dramatic increase in shock rate was associated with lowered responding during time-out. Subject NSIG 3 seemingly went through the entire experiment without learning that time-out periods were given.

\section{DISCUSSION}

The results given above showed that whether an avoidance response rate will come under the influence of a transitory extinction (time-out) schedule depended upon one of two variables: (1) the presence of a signal for the time-out period and (2) the proportion of the session assigned to time-out. The finding that the response rate diminished during signaled timeout was not unexpected based on previous reports (cf., Appel, 1960a; Hurwitz \& Roberts, 1971; Roberts \& Hurwitz, 1970). But even in the presence of the signal, reponding in time-out well above a minimal level was found, which leads to the importance of the second variable. With both signaled and unsignaled conditions, the extent of the response rate decrease from baseline was related to the proportion of the session assigned to time-out. For example, moderate levels of responding during the signaled time-out periods were found in Phase $1: 3$ (the first 75-sec time-out). A similar maintenance of response rate was found by Roberts and Hurwitz (1970) when the pro- portion of time-out to avoidance was $1: 5$ (with 60-sec time-out periods). But when more of the session involved time-out, responding during time-out reduced to minimal levels.

This variable was particularly important when time-out was unsignaled: The shorter the time-out period, the less the discrimination. Indeed, the response rate decreased substantially only when unsignaled time-out constituted the greater proportion of the session, as in Phase $1: 3$. Moreover, when the shock values are consulted, the basis for the NSIG subjects discrimination is apparent: The discrimination developed only because avoidance deteriorated. Lacking a specific stimulus to indicate the presence of time-out, these subjects probably relied on the delivery of (unavoided) shocks to differentiate the avoidance from the time-out components, a suggestion previously made by Sidman (1966, p. 484-486). Since time-out was scheduled aperiodically, the NSIG subjects apparently risked avoidable shocks to determine when the period of no shock was present; similarly, the delivery of shock served to indicate the return to the avoidance condition. While individual differences were present, the data suggest that the "risk" was worth taking, especially when a large proportion of the session was allotted time-out (i.e., Phase 1:3 compared to the $3: 1$ replication). Additional research is needed, however, to isolate the relative contributions of time-out duration, the proportion of avoidance to time-out, and their probable interaction, to the development of the discrimination between unsignaled avoidance and time-out.

\section{REFERENCES}

APPEL, J. B. The aversive control of an operant discrimination. Journal of the Experimental Analysis of Behavior, 1960, 3, 35-47. (a)

APPEL, J. B. Some schedules involving aversive control. Journal of the Experimental Analysis of Behavior, 1960, 3, 349-359. (b)

HuRwitz, H. M. B., \& Roberts, A. E. Timeout as a determinant of rate of response and rate of avoidance. Psychonomic Science, 1971, 24, 131-133.

Sidman, M. Avoidance conditioning with brief shock and no exteroceptive warning signal. Science, 1953, 118, 157-158.

Sidman, M. Avoidance behavior. In W. K. Honig (Ed.), Operant behavior: Areas of research and application. AppletonCentury-Crofts, 1966. Pp. 448-498.

Roberts, A. E., \& HuRwitz, H. M. B. The effect of a pre-shock on a free-operant avoidance response. Journal of the Experimental Analysis of Behavior, 1970, 14, 331-340.

(Received for publication April 18, 1978.) 